\title{
ONE MONTH POST INTENSIVE CARE UNIT DISCHARGE OUTCOME
}

\author{
Nadeem Siddique, Muhammad Ahmad, Sabir Khan, Arshad Taqi, Tanvir Hussain
}

National Hospital and Medical Centre, Lahore Pakistan

\begin{abstract}
Objective: To determine the outcomes of patients discharged from a general intensive care unit one month after discharge.

Study Design: Descriptive case series.

Place and Duration of Study: Intensive Care Unit - National Hospital and Medical Centre Lahore, from Jan 2018 to Dec 2018.

Methodology: All patients of both genders and age more than 12 years were included. Follow up was done through a phone call to the contact number provided, one-month post intensive care unit discharge. Information regarding outcome i.e. survival, bed bound state, degree of dependence for day to day activities and return to routine life.

Results: A total of 106 cases were recruited, out of which $55.7 \%$ were male and $44.3 \%$ female; mean age was $56.86 \pm 23.16$ years. At 1-month intensive care unit discharge $8.49 \%$ of the patients were dead; $73.58 \%$ cases had returned to pre intensive care unit admission routines, $11.32 \%$ were partially dependent on someone, $6.6 \%$ were bed bound. Death and bed bounding was highest in 60 year or older patients $(p=0.03)$. All 9 cases who had died and 7 who were bed bound were admitted through emergency and remained admitted in the hospital for more than 7 days with $p=0.0001$. $77.8 \%$ of patients who died, $66.7 \%$ of patients who were partially dependent and all the bed bound patients required needed ventilation during intensive care unit admission with $p=0.0001$.

Conclusion: In our series $20 \%$ of the patients were either dead or dependent for their daily survival one month after discharge from intensive care unit.
\end{abstract}

Keywords: Death, Intensive care unit, Medical, Surgical.

This is an Open Access article distributed under the terms of the Creative Commons Attribution License (http://creativecommons.org/licenses/by/4.0), which permits unrestricted use, distribution, and reproduction in any medium, provided the original work is properly cited.

\section{INTRODUCTION}

Intensive care units (ICU) have played agreatrole in the survival of the critically ill patients; critical illness and its management in the ICU has a major impact on short and long term survival and quality of life. This impact is becoming more pronounced with availability of bigger data and resulting awareness about emerging trends ${ }^{1,2}$.

There are number of leading diagnosis that need cardiovascular or respiratory support or in cases of neurosurgical or neurology diagnosis, monitory of the consciousness can be one factor that lead to ICU stay; which itself adds to over mental or psychological trauma due to fear of intensive care admission. The other factors like isolation from the family, bed bound state, extensive medications also add to overall morbidity ${ }^{3}$.

Correspondence: Dr Nadeem Siddique, Intensive Care Unit, National Hospital and Medical Centre, Lahore Pakistan Received: 19 May 2019; revised received: 20 Nov 2019; accepted: 29 Nov 2019
More recently, major complications in ICU discharge include death, serious disability leading to bed bound state, focal deficit leading to temporary or permanent disability, wide range of cognitive dysfunctions, myopathies, depression anxiety etc. and all are covered under a wide domain of post- intensive care syndrome (PICS) ${ }^{4,5}$.

The major predictors of the outcome in these survivor for their morbidity or physical well being include underlying disease, physical status at presentation, Glasgow coma scale (GCS) in neurological cases, length of hospital stay and mode of admission i.e. elective versus emergency ${ }^{6-8}$.

There are many tools and questioners for the assessment of functional and outcome status regarding both physical, mental and psychological state at post ICU discharge, but they are too complex and sometimes difficult to implement in basis level settings especially in the under developed countries. The data in post ICU discharge 
cases in Pakistan is lacking, that's why this study was plannedat more of the fundamental level, whose target was to sensitize the community and bring a basic level foundation from which complex and more validated tools assisted studies can be done. The objective of this study was to determine the one month outcome in post ICU discharge cases.

\section{METHODOLOGY}

This was a descriptive case series study that was carried out at National Hospital and medical centre, Lahore during January 2018 to December 2018. The cases of both genders and age $>12$ years were included. The cases were selected irrespective of the diagnosis leading to ICU admission. The cases that were not contacted or not willing to disclose the information were excluded from the study. The detailed clinical information regarding type of diagnosis (medical/surgical), mode of admission (elective/emergency) and history of ventilation was taken. These cases were assessed at one-month post ICU discharge regarding different outcome i.e. death, bed bound state, partially dependence on someone for day to day activities or back to routine life.

\section{Statistical Analysis}

The data was entered and assessed by using SPSS version 23.0. Qualitative variables were presented in the form of frequency and percentages and quantitative variables were presented as mean and standard deviation. Post stratification chi square test was applied taking $p$-value of $\leq 0.05$ as significant.

\section{RESULTS}

In this study there were total 106 cases, out of which $55.7 \%$ males and $44.3 \%$ females with a mean age of $56.86 \pm 23.16$ years. There were $52.8 \%$ of the cases admitted for surgical causes and $50.9 \%$ were elective admissions as shown in table-I. At 1-month ICU discharge $73.58 \%$ cases were back to work, $11.32 \%$ were partially dependent due to some physical disability, $6.6 \%$ were bed bound and $8.49 \%$ were dead as in figure. There was no significant difference in terms of gender and outcomes with $p=0.86$ (table-II). Dea- th and bed bounding was highest in cases with age 60 or more years with $p=0.03$ as in table-IV. One-month mortality was seen in all 9 cases and the all 7 bed bound cases were seen in cases that had admission due to emergency cause and hospital admission for more than 7 days with $p=0.0001$

Table-I: Demographics of study subjects.

\begin{tabular}{l|c|c}
\hline Variables & Mean \pm SD & Range \\
\hline Age & $56.86 \pm 23.16$ & $13-92$ \\
\hline Hospital stay & $7.04 \pm 5.41$ & $1-35$ \\
\hline Variables & Frequency & \%age \\
\hline Male & 59 & 55.7 \\
\hline Female & 47 & 44.3 \\
\hline H/o ventilator & 38 & 35.8 \\
\hline H/o no ventilator & 68 & 64.2 \\
\hline Medical cause & 50 & 47.2 \\
\hline Surgical cause & 56 & 52.8 \\
\hline Elective & 54 & 50.9 \\
\hline Emergency & 52 & 49.1 \\
\hline
\end{tabular}

\begin{tabular}{l|c|c|c}
\hline \multirow{2}{*}{ Table-II: Outcome with respect to gender. } & \multicolumn{2}{|c}{ Outcome } & \multicolumn{2}{|c}{ Cause of admission } & \multirow{2}{*}{$\begin{array}{c}\text { - } \\
\text { value }\end{array}$} \\
\cline { 2 - 3 } & $\begin{array}{c}\text { Elective } \\
\mathbf{n}(\mathbf{\%})\end{array}$ & $\begin{array}{c}\text { Emergen } \\
\text { cy, } \mathbf{n}(\mathbf{\%})\end{array}$ & \\
\hline Death & $4(44.4)$ & $5(55.6)$ & \\
\hline Back to routine life & $45(57.7)$ & $33(42.3)$ & \multirow{2}{*}{0.86} \\
\hline Partially dependent & $6(50)$ & $6(50)$ & \\
\hline Bed bound & $4(57.1)$ & $3(42.9)$ & \\
\hline Total & $59(55.6)$ & $47(49.06)$ & 106 \\
\hline
\end{tabular}

Table-III: Outcome with respect to age.

\begin{tabular}{|c|c|c|c|c|}
\hline \multirow[b]{2}{*}{ Outcome } & \multicolumn{3}{|c|}{ Age } & \multirow[b]{2}{*}{$\begin{array}{c}p- \\
\text { value }\end{array}$} \\
\hline & $\begin{array}{c}<30 \\
\text { n }(\%)\end{array}$ & $\begin{array}{l}30-59 \\
\text { n ( } \%)\end{array}$ & $\begin{array}{c}\geq 60 \\
\text { n ( } \%)\end{array}$ & \\
\hline Death & $2(22.2)$ & 1(11.1) & $6(66.7)$ & \multirow{4}{*}{0.03} \\
\hline $\begin{array}{l}\text { Back to } \\
\text { work }\end{array}$ & 14(17.9) & $34(43.6)$ & $30(38.5)$ & \\
\hline $\begin{array}{l}\text { Partially } \\
\text { dependent }\end{array}$ & $3(25)$ & $1(8.3)$ & $8(66.7)$ & \\
\hline Bed bound & - & $1(14.3)$ & $6(85.7)$ & \\
\hline Total & 19(17.92) & $37(34.90)$ & $50(47.18)$ & 106 \\
\hline
\end{tabular}

Table-IV: Outcome with respect to diagnosis at admission.

\begin{tabular}{l|c|c|c}
\hline \multirow{2}{*}{ Outcome } & \multicolumn{2}{|c|}{ Diagnosis at Admission } & \multirow{2}{*}{$\begin{array}{c}\boldsymbol{p} \text { - } \\
\text { value }\end{array}$} \\
\cline { 2 - 3 } & $\begin{array}{c}\text { Medical } \\
\mathbf{n}(\mathbf{\%})\end{array}$ & $\begin{array}{c}\text { Surgical } \\
\mathbf{n}(\mathbf{\%})\end{array}$ & \\
\hline Death & $8(88.9)$ & $1(11.1)$ & \\
\hline Back to work & $31(39.7)$ & $47(60.3)$ & \multirow{2}{*}{0.02} \\
\hline $\begin{array}{l}\text { Partially } \\
\text { dependent }\end{array}$ & $6(50)$ & $6(50)$ & \\
\hline Bed bound & $5(71.4)$ & $2(28.6)$ & \\
\hline Total & $50(47.17)$ & $56(52.83)$ & 106 \\
\hline
\end{tabular}


each as shown in table-V \& VI. There were $77.8 \%$ dead cases, $100 \%$ bed bound and $66.7 \%$ cases that were partially dependent who needed ventilation during ICU admission with $p=0.0001$ (table-VII).

Table-V: Outcome with respect to cause of admission.

\begin{tabular}{|c|c|c|c|}
\hline \multirow[b]{2}{*}{ Outcome } & \multicolumn{2}{|c|}{ Cause of Admission } & \multirow[b]{2}{*}{$\begin{array}{c}p \text { - } \\
\text { value }\end{array}$} \\
\hline & $\begin{array}{c}\text { Elective } \\
\text { n ( } \%)\end{array}$ & $\begin{array}{c}\text { Emergency } \\
\text { n (\%) }\end{array}$ & \\
\hline Death & - & $9(100)$ & \multirow{4}{*}{0.0001} \\
\hline Back to work & $52(66.7)$ & $26(33.3 \%)$ & \\
\hline $\begin{array}{l}\text { Partially } \\
\text { dependent }\end{array}$ & $2(16.7)$ & $10(83.3)$ & \\
\hline Bed bound & - & $7(100)$ & \\
\hline Total & $54(50.94)$ & $52(49.06)$ & 106 \\
\hline \multicolumn{4}{|c|}{ Table-VI: Outcome with respect to Hospital stay. } \\
\hline \multirow[b]{2}{*}{ Outcome } & \multicolumn{2}{|c|}{ Hospital Stay (days) } & \\
\hline & $\begin{array}{l}\text { Up to } 7 \\
\text { n }(\%)\end{array}$ & $\begin{array}{c}>7 \\
\text { n }(\%)\end{array}$ & $\begin{array}{c}p- \\
\text { value }\end{array}$ \\
\hline Death & - & $9(100)$ & \multirow{4}{*}{0.0001} \\
\hline Back to work & $68(87.2)$ & $10(12.8)$ & \\
\hline $\begin{array}{l}\text { Partially } \\
\text { dependent }\end{array}$ & $2(16.7)$ & $10(83.3)$ & \\
\hline Bed bound & - & $7(100)$ & \\
\hline Total & $70(66.03)$ & $36(33.97)$ & 106 \\
\hline
\end{tabular}

Table-VII: Outcome with respect to Ventilator therapy.

\begin{tabular}{l|c|c|c}
\hline \multirow{2}{*}{ Outcome } & \multicolumn{2}{|c|}{ Ventilator Therapy } & \multirow{2}{*}{$\begin{array}{c}\boldsymbol{p} \text { - } \\
\text { value }\end{array}$} \\
\cline { 2 - 3 } & $\begin{array}{c}\text { Yes } \\
\mathbf{n}(\%)\end{array}$ & $\begin{array}{c}\text { No } \\
\mathbf{n}(\%)\end{array}$ & \\
\hline Death & $7(77.8)$ & $2(22.2)$ & \\
\hline Back to work & $16(20.5)$ & $62(79.5)$ & \multirow{2}{*}{0.0001} \\
\hline $\begin{array}{l}\text { Partially } \\
\text { dependent }\end{array}$ & $8(66.7)$ & $4(33.3)$ & \\
\hline Bed bound & $7(100)$ & - & \\
\hline Total & $38(35.9)$ & $68(64.1)$ & 106 \\
\hline
\end{tabular}

\section{DISCUSSION}

Critical illness has a great impact not only in short term basis but also after the discharge from the ICU settings. Achievement of the baseline activity or optimal life style is a great challenge and there is significant physical, social, psychological and emotional affect of ICU admission in case needing it ${ }^{11}$.

In the present study outcome was assessed at 1-month after ICU discharge and it was seen that after this time $73.58 \%$ cases were back to their baseline routine life, $11.32 \%$ were partially dependent due to some ailment, $6.6 \%$ were bed bound and mortality was seen in $8.49 \%$ of the cases. The results were very variable in the past and depends of upon the degree of severity of the including patients and also the variation of the available resources in the developed and under developed countries11,12. According to a study done by Wise et al it was seen that mortality was seen in $59(25.9 \%)$ of their cases within 30 days, which was three times more than the present study ${ }^{12}$.

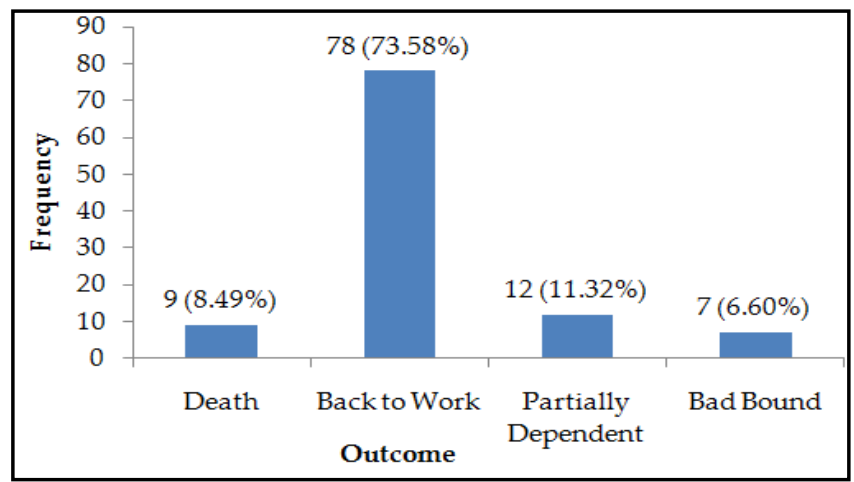

Figure: Outcome.

One-month mortality was seen in all 9 cases and the all 7 bed bound cases were seen in cases that had admission due to emergency cause and hospital admission for more than 7 days with $p=0.0001$. These results were also supported by the findings of the studies done in the past which have shown that mortality rate ranged from 20 $25 \%$ cases that had admission on emergency grounds. Furthermore, they also revealed that the length of hospital stay was also longer in cases that were admitted due to emergency admissions 13,14 . This can be explained by the factor that the cases that were electively admitted had a better clinical condi tion as compared to critically ill crashing in emergency. As these cases can be post cardiac arrest and hypoxic injuries due to respiratory or cardiac failure can result in an irreversible cardiac or neurological damage that can be fatal. Further more it was also observed that even worst outcome was observed in cases that needed ventilation during the course of their treatment in ICU and it was observed that $77.8 \%$ dead cases, $100 \%$ bed bound and $66.7 \%$ cases that 
were partially dependent were ventilated in ICU with $p=0.0001$. This can indirectly explain the seriousness of the underlying condition or may be post respiratory of cardiac even sequel that led to ventilatory assistance and hence its associated complications. The major complications that lead to fatality and the bed bound state can be ventilator associated pneumonia (VAP), myopathies and delirium can be the possible causes to explain this.

In another study done by Uppanisakorn et al it was seen that early deterioration was observed in $14.8 \%$ of the cases after ICU discharge and the cases that led to cardiac or respiratory failure within 24 hours of admission led to poor outcome and for that, they devised a score called as National early warning score (NEWS) to predict the post ICU discharge outcome and a score of NEWSdc $>7$ had sensitivity and specificity of $93.6 \%$ and $82.2 \% 15$.

In another study done by Duarte et al it was seen that after ICU discharge there were a number of limitations in the activities. Reduction in peripheral muscle strength was seen in 5.7\%, weight loss in $11.7 \%$, abnormal spirometry in $49 \%$ and psychological issues in $49 \%$ of the cases ${ }^{16}$. Post ICU discharge psychosis, delirium, myopathies and neuropathies are well known entities and one important cause of bed bound state.

In our study there were $52.8 \%$ of the cases admitted for surgical and $47.2 \%$ medical causes and $50.9 \%$ were elective admissions and the rest had emergency admissions. The results were variable in the past and majority of them revealed that emergency admissions were higher and furthermore, $25-38 \%$ of the cases were admitted for infectious causes ${ }^{17}$. The outcomes and morbidity and mortality rates strongly rely upon the type of ICU care, which can further be divided into medical, surgical, neuro ICU and can be mix of these. As in surgical and neuro surgical cases, the majority of the admissions are elective as compared to medical ICUs where, a great burden of the cases end up with organ failures and hence have poor outcome in terms of mortality rate, bed bou- nd state and with need of home care for longer term management ${ }^{18,20}$.

\section{CONCLUSION}

The outcome after ICU discharge is variable and almost $20 \%$ of the cases either die or become dependent due some physical limitation. The worst outcome was seen in cases with higher age, emergency hospital admission, medical causes, longer hospital stay and history of ventilation in ICU.

\section{CONFLICT OF INTEREST}

There is no conflict of interest to be declare by any author.

\section{REFERENCES}

1. Scheuremann LP, White DB. The ethics and reality of rationing in medicine. Chest 2011; 140(6): 1625-32.

2. Naidoo K, Singh J, Lalloo U. A critical analysis of ICU/HC beds in South Africa: 2008-2009. S Afr Med J 2013; 103(10): 751-73.

3. Stow P, Hart G, Higlett T, George C, Herkes R, McWilliam D, et al. Development and implementation of a high-quality clinical database: the Australian and New Zealand Intensive care society adult patient database. J Crit Care 2006; 21(2): 133-41.

4. Adhikari NKJ, Fowler RA, Bhagwanjee S. Critical care and the global burden of critical illness in adults. Lancet 2010; 376(9749): 1339-46.

5. Joynt KE, Orav EJ, Jha AK. Mortality rates for Medicare beneficiaries admitted to critical access and non-critical access hospitals, 2002-2010. J Am Med Assoc 2013; 309(13): 1379-87.

6. Docking R, Mackay A, Williams C, Lewsey J, Kinsella J, Booth MG. Comorbidity and intensive care outcome - A multivariable analysis. J Crit Care Med 2014; 15(3): 205-12.

7. Needham DM, Davidson J, Cohen H, Hopkins RO, Weinert C, Wunsch $\mathrm{H}$, et al. Improving long-term outcomes after discharge from intensive care unit: report from a stakeholders' conference. Crit Care Med 2012; 40(2): 502-09.

8. Vincent JL, Marshall JC, Namendys-Silva SA, Francois B, Martin-Loeches I, Lipman J, et al. Assessment of the worldwide burden of critical illness: the intensive care over nations (ICON) audit. Lancet Respir Med 2014; 2(5): 380-86.

9. Braun A, Chang D, Mahadevappa K, Gibbons FK, Liu Y, Giovannucci E, et al. Association of low serum 25-hydroxyvitamin D levels and mortality in the critically ill. Crit Care Med 2011; 39(4): 671-77.

10. Lecky F, Woodford M, Edwards A, Bouamra O, Coats T. Trauma scoring systems and databases. Br J Anaesth 2014; 113(2): 28694.

11. Orwelius L, Nordlund A, Nordlund P, Simonsson E, Backman C, Samuelsson A, et al. Pre-existing disease: the most important factor for health related quality of life long-term after critical illness: a prospective, longitudinal, multicentre trial. Crit Care 2010; 14(2): R67.

12. Wise R, de Vasconcellos K, Skinner D, Rodseth R, Gopalan D, Muckart D, et al. Outcomes 30 days after ICU admission; the 30DOS study. South Afr J Anaesth Analg 2017; 23(6): 139-44.

13. Desai SV, Law TJ, Needham DM. Long-term complications of critical care. Crit Care Med 2011; 39(2): 371-79. 
14. Luangasanatip N, Hongsuwan M, Lubell Y, Limmathurotsakul $D$, Teparrukkul $\mathrm{P}$, Chaowarat $\mathrm{S}$, et al. Long-term survival after intensive care unit discharge in Thailand: a retrospective study. Crit Care 2013; 17(5): R219.

15. Uppanisakorn S, Bhurayanontachai R, Boonyarat J, Kaewpradit J. National early warning score (NEWS) at ICU discharge can predict early clinical deterioration after ICU transfer. J Crit Care 2018; 43(1): 225-29.

16. Duarte PA, Costa JB, Duarte ST, Taba S, Lordani CR, Osaku EF, et al. Characteristics and outcomes of intensive care unit survivors: experience of a multidisciplinary outpatient clinic in a teaching hospital. Clinics 2017; 72(12): 764-72.

17. Mebazaa A, Casadia MC, Azoulay E. Post-ICU discharge and outcome: rationale and methods of the The French and european
Outcome reGistry in Intensive Care Units (FROG-ICU) observational study. BMC Anestheiol 2015; 143(15): 1-9.

18. Muller G, Flecher E, Lebreton G, Luyt CE, Trouillet JL, Brechot $\mathrm{N}$. The ENCOURAGE mortality risk score and analysis of longterm outcomes after VA-ECMO for acute myocardial infa-rction with cardiogenic shock. Intensive Care Med 2016; 42(3): 370.

19. Pan HC, Jenq CC, Tsai MH, Fan PC, Chang CH, Chang MY, et al. Scoring systems for 6-month mortality in critically ill cirrhotic patients: a prospective analysis of chronic liver failure - sequential organ failure assessment score (CLIF-SOFA). Aliment Pharmacol Ther 2014; 40(9): 1056-65.

20. French-O'Carroll R, Frohlich S, Murphy N, Conlon N. Predictors of outcome in decompensated liver disease: validation of the SOFA-L score. Ir Med J 2015; 108(1): 114-16. 